\title{
HOT TEMPER, MELTED HEART: WHITMAN'S DEMOCRATIC (RE)CONVERSION, MAY 1863
}

\author{
Paul Benton
}

WHITMAN WAS A WRITER, the kind of person who was always writing things down. He seldom left home without a pencil and a small notebook in his pocket for recording observations and inspirations. In a pinch he would recycle a scrap of paper or the back of an envelope. Some of these drafts and jottings eventually made their way into his poetry or journalism. Most did not. Some of them he burned in a couple of quick efforts at house-cleaning. But he kept so many that visitors to his Camden room late in his life often noticed an ankle-deep pool of scattered paper around his chair.

What looked like a pile of trash back then is now, of course, a valuable resource for understanding Whitman and his work. And thanks to the hefty editions by William White in 1978 and Edward Grier in 1984, nine volumes all together, almost all of these rough notes and drafts are now available, more or less, in every academic library. Yet scholars have made surprisingly little use of these manuscripts. Why? In part, at least, because the editors of Whitman's unpublished prose, from the initial troika of literary executors to White and Grier, so re-organized what they found that readers who lack access to the original documents have had difficulty realizing what is really there.

Perhaps the most egregious example of this tradition of editorial obfuscation is the set of six consecutive drafts of a new prose introduction to Leaves of Grass that Whitman wrote during the Civil War years, six booklets that he eventually pasted with archival deliberateness into his sole remaining copy of the 1855 edition, which is now in the Lion Collection at The New York Public Library. I am working on a facsimile edition of these Lion drafts, an edition that will make evident how much scholars have missed by relying on the editorial work of Grier and his predecessors. But here I would like to consider a much smaller and simpler case, a fascinating set of three passages on "Democracy" that Whitman wrote in the late spring of 1863, drafting them on the blank pages at the end of a daybook. I begin with a fresh transcription of those rough holographs, based on microfilm of Whitman's daybook, which is now in the Harned Collection at the Library of Congress (LC \#98, Reel 2:81-84). 
[142] <Finale > Finate for (Democracy) - Yet through War itself-aye through these hells, these thrice hot hells of <civil> war-through flashing bayonets \& out many a volley-through the eha yells of the men \& the eotonel's colonel's cries <leading with unsheathed sword the cries $>$ of charge! charge!-through falling? pht of the minnie- \& the bursting of shells, <the thud of the great ball falling on the ground $>$ and whistling of round shot, $\&$ the wild shriek of the rifled ean pounder [143] -through <though $>$ the fields are covered with dying and with dead - and the hospitals crowded long \& long with wounded \& with sick and -out of all that \& the like, eontained <and the $>$ ghastly face, just dead upon the cot <outside the tent $>$ and the other form throw on? < upon the ???> a stretcher covered with a <???> dark gray blanket, and waiting to be buried, for these, $\&$ worse [144] than these if worse than these there be $<$ if any thing more monstrous, more unnatural be than these others $>$, Democracy goes on the modern soul $<$ America $>$ goes on, and $<$ must $\&>$ shall go on.

[145, extreme top margin] saw portrait of Prince of Wales on a Penn av car in Washington May 363

\section{[146-151 blank]}

[152] About this business of Democracy \& human rights \&c, often comes the query-as you <one> sees the setf shallowness and miserable selfishness<ism> of vast <these $>$ crowds of men, with all their minds so blank of high honor \& humanity $<\&$ aspiration $>$ - the $<$ then $>$ comes the terrible query <and will not be denied $>$ whether the idea of <is faith [?] [in] > Democracy \& < in this thing > of human rights is not a great humbug after all- whether <are> these shaltow flippant and people with hearts of rags \& souls $<$ of $>$ chalk are $<$ these $>$ worth [153] preaching for after alt $<\&$ dying for upon the cross $>$ ? May be not - may be it is indeed a dream $-<$ yet one thing sure remains $\rightarrow$ but the exercise of Democracy <equality to him who believing preaches and to the people who work it out this $>$ is not a dream - to work for it $<$ Democracy $>$ is good, the exercise is good - It strengthens strength it makes \& lessons it teaches-gods it makes at any rate, though it crucifies them often.

\section{[154 blank]}

[155] < in dim outline (I see) we see> Picture of < strong> Imperial Stern Democracy, its attitude \& gesture toward the south, <toward> this hot rebellious rise we call the south-If then you will not own your fate but dare to lift the knife against to plunge it at my breast, learn what it is to rouse the devil-on your head be the red blood, and on your children's heads, for whether now, or in a year or ten or twenty years, my hand will have [156] $\leftarrow$ see over $\leftarrow$ May 2, '63-Saw the procession of rebel prisoners (about 100) march down Pennsylvania av. under guard, to the Old Capitol prison. We talk brave \& get excited \& indignant over the "rebels," \& drink perdition to them-but I realized how all anger sinks into nothing, in eon sight of these young men $\&$ standing close by them, $\&$ seeing them pass. They were wretchedly drest, very dirty $\&$ playedout in worthless in rig, but generaly bright good looking fellows-I felt that they were my brothers just about the same as the rest-I felt my heart full of compassion [157] \& brotherhood, $\&$ the <irrepressible > <absurd $>$ tears started in my eyes. - these too are my brothers-it was in the look of them \& in my heart the common people these, American, silent proud young fellows - (there was not one single expression of insult or in comment from the crowd along Pennsylvania avenue-not the slightest-the prisoners were surrounded with a cordon of guards with loaded muskets) [158] - to haave [sic] suffered! what a title it gives! - all the honors, the President <at his levee>, the ribbon'd \& starr'd ambassadors, the $-\ldots$ the 
no these must \& shall yield place, curious as it seems, to prisoners ?? mmer guard in war clothes, with wretched blankets, marched to prison, surrounded by armed guards - these must yield to the amput?? poor boys, faint \& sick in hospitals with suff? without grace, have not an eye for pictures [159] have <?> not read the elder poets, but have tost th ?? ? amputated limbs

In 1928, Clifton Joseph Furness published part of the longest and last of these three drafts in the heterogeneous collection of unpublished material he edited under the title Walt Whitman's Workshop. ${ }^{1}$ As Whitman wrote it in his daybook, the crux of this passage is a sudden rhetorical shift - a turn away from a personified Democracy who angrily curses the rebellious South, a turn toward a compassionate recognition of democratic brotherhood with a group of captured rebels. ${ }^{2}$ Unfortunately, however, Furness managed to get only the beginning and the ending of this passage into his edited version, silently and no doubt unconsciously skipping two and a half pages of Whitman's text in mid-sentence, without even the hint of an ellipsis. ${ }^{3} \mathrm{He}$ thus manufactured a misleading syntactic muddle that thoroughly obscured Whitman's point. ${ }^{4}$

In 1933 Charles Glicksberg published another version of this same passage as part of what he called Whitman's "Diary for 1863." Glicksberg's version was also fatally truncated, but in a quite different way. Apparently because he thought only dated material should appear in a "diary," he silently excluded the (undated) first part of this passage, the essential first scene without which the reversal in the second scene is not fully intelligible.

What about the other two "Democracy" drafts from this 1863 daybook? Glicksberg left both of them out, presumably because they were undated. Furness had included the earliest one, the one beginning "Finale for (Democracy)," but he placed it in a different section of his collection, without any reference to the passage on Whitman's response to the captured rebels. ${ }^{6}$

Edward Grier did better: he at least managed to publish all three passages in his 1984 edition of Whitman's Notebooks and Unpublished Prose Manuscripts. ${ }^{7}$ But Grier still made it difficult to grasp what Whitman had done, because he too chose not to present the three drafts page for page, in the order they appear in Whitman's daybook. Instead, like Glicksberg, he tried to perfect the putative "diary" by rearranging its pages, printing all dated passages in chronological order, and leaving miscellaneous undated material at the end. Since the three "Democracy" passages are undated-with one crucial exception-they were kept together, mostly. ${ }^{8}$ The exception, however, created a huge gap: in Grier's edition the third and most important piece ends with mysterious abruptness because its last four pages, including the crucial reversal to which I have alluded, had already appeared as a May 2 "diary" entry ten pages earlier. ${ }^{9}$ This is especially surprising and disconcerting because Whit- 
man had marked that concluding May 2 passage on page 156 with an imperative "See over," sandwiching that emphatic connective between two visually striking hands that point back to the left. Back to what? Surely back to page 155, the immediately preceding recto in the daybook. But that obvious connection evaporates in the NUPM version, where page 155 appears ten pages after page $156 !^{10}$ In short, as a result of his chronological reordering of pages, Grier severed the crucial link between Democracy's melodramatic cursing of the South (Daybook 155, NUPM 543) and Whitman's subsequent discovery of democratic brotherhood with rebel prisoners (Daybook 156-159, NUPM 533). Only the slender thread of a single footnote crosses the ten-page gap Grier created, and unfortunately that note is both misplaced and hidden by a flurry of typographical errors. ${ }^{11}$

As a consequence of all this editorial selecting and reordering, beginning with Furness and Glicksberg, continuing with Grier, no scholar has yet noticed that Whitman's third passage on "Democracy" is worth careful analysis, especially when it is read as a whole and as the culmination of a short series of drafts on the same subject. It is almost as if we had discovered a new set of Whitman texts, hidden here in the curious convolutions Whitman's editors have created. Before looking closely at these three "new" pieces, however, we should refresh our memory about their biographical context, about what Whitman was up to in the spring of 1863.

Whitman had hurriedly left Brooklyn in mid-December 1862 to find his brother George, a Union officer wounded in the assault on the heights of Fredericksburg. But Whitman had another motive too: he went to the front lines in Virginia as a writer, eager for new material. He traveled light, with so few clothes that he soon found his pants worn through at the knees and his shirts falling apart. He found room, however, for a pocket-sized journal (2.75" $\mathrm{x} \mathrm{4.5")}$ that he had used back in Brooklyn, and he immediately began filling it with observations of camp life and with an anecdotal history of George's regiment. ${ }^{12}$ By the time he took the boat back up the Potomac on December 28, Whitman had resolved to stay on in Washington, as he wrote Emerson the next day, "until I get out of horrible sloughs"-by which he meant, I think, both getting a job and breaking out of his "New York stagnation" as a writer. ${ }^{13}$ Thanks to free meals from his friends the O'Connors, Whitman earned enough as a part-time copyist for the army paymaster and from occasional freelance articles for New York papers to maintain himself in spartan fashion, in "a sort of German or Parisian student life," as he wrote his Manhattan friend Nat Bloom. ${ }^{14} \mathrm{He}$ had lots of free time and he spent much of it as an observer-peering down on Congress from the gallery, sauntering through the Capitol grounds, watching troops pass along Pennsylvania Avenue or Lincoln ride up 14th Street with his 
escort, watching sometimes from the curb, sometimes from his fifthfloor office near the White House, sometimes from his small third-floor room a few blocks north. He used many of these observations in his articles for the New York press, for which he specialized more in the local color of the nation's capital than in politics or war news. ${ }^{15}$

But almost from the beginning Whitman discovered another, and deeper, reason for staying on in Washington. On Friday, January 2, at the end of his first week back from the front lines, Whitman walked over to Campbell Hospital to visit a couple of Brooklyn boys from George's regiment. He was moved by what he found. "O my dear sister," he wrote Martha the next day, "how your heart would ache to go through the rows of wounded young men, as I did-and stopt to speak a comforting word to them." 16 Here was a more profound way out of his slough. In the hospitals he was a participant, not just an observer. Here his identity as a writer was submerged in the pressing need to be a caring human being. Or rather his writerly identity was changed, converted or reconverted, as he moved from cot to cot and began to think about writing a little book of prose that would make clear, as he soon put it in a letter to Emerson, how he had found "the best expression of American character I have ever seen or conceived-practically here in these ranks of sick and dying young men." 17

In addition to his journalism and work on this new book, Whitman spent many hours in the spring of 1863 writing letters-for and to the soldiers he met in the wards, to his Manhattan buddies, to his mother and brothers and sisters. Again and again he emphasized what he now called his "missionary work" in the hospitals, a commitment that required still more letters, soliciting donations and thanking donors. By April he had begun using a commercially printed 1862 diary (emended by hand for 1863 dates) to record letters sent and received, together with occasional brief notes on his daily activities. It was on the pages for "cash accounts" and "bills payable" at the end of this daybook that Whitman drafted his three short pieces on "Democracy," probably in April and May, around the time of General Hooker's ill-fated battle at Chancellorsville.

For what were these passages drafted? They look nothing like his 1863 journalism, very little like any poem he would ever write. And they are unlike anything in the slender book he would eventually publish as Memoranda During the War. But there was one other potential forum. Whitman wrote his mother in early June that he was considering "a series of lectures \& readings ... to supply myself with funds for my Hospital \& Soldiers visits."18 Quite possibly these pieces on "Democracy" were drafted for that kind of public oration. Such lectures would probably have had at their core the individual stories of suffering and courage he recorded so movingly in his letters and journalism. But one 
can imagine that Whitman thought he should supplement the quiet voice of the witness with the broader, more dramatically eloquent voice of the orator, using what he had observed at or near the front lines to illuminate the larger significance of the war.

If I am right about the purpose of these three drafts, then it seems especially significant that the topic Whitman chose was not "Union," that transcendent ideal and constitutional institution threatened by Secession. Nor was it "Emancipation," the revolutionary extension of liberty to all Americans, black as well as white. Instead he invented a series of dramatic scenes in which a vaguely personified "Democracy" is physically and psychologically tested by war. In effect he projected himselfand through himself his audience - into an ordeal that challenges the democratic spirit. Could Democracy imagined in this personal way endure such a war? Would Democracy be perverted, overcome by private cynicism or totalitarian rage? Or would war serve as a baptism of fire through which our democratic spirit could be born again?

The first of Whitman's three short drafts has the title "Finale," which I suspect refers to the role this paragraph might have played in Whitman's oration. ${ }^{19}$ Most of the passage is devoted to what Whitman calls the "thrice hot hells of <civil> war." 20 It opens with a sensational re-enactment of the frenzy of battle, with emphasis on the sounds of violence, on the heroic cries of "charge! charge!" in the midst of an aural flood of shrieking bullets and bursting shells and thudding cannon balls. At the end of the battle comes the second hell, the sickening panorama of "fields . . . covered with dying and with dead-and the hospitals crowded long \& long." And finally comes the hell of dealing with the individual corpse, "the ghastly face, just dead upon the cot outside the tent."

None of this says much about the substance or value of democracy. Whitman's focus is rather on the nightmare through which a personified Democracy, defined only as a suffering agent, must and will persevere and prevail. He emphasizes the need for Democracy to face the horror of violence and death without losing the courage to keep going. The war now seemed to him, as he wrote his mother after Gettysburg, "like a great slaughter-house $\&$ the men mutually butchering each other." 21 But such honest revulsion must not lead to surrender or fatalistic despair. As he puts it at the end of this first piece: "if any thing more monstrous, more unnatural than these there be Democracy goes on the Modern soul <America $>$ goes on, and <must $\&>$ shall go on." 22 It was, in fact, this capacity to "go on" despite incredible suffering that so impressed him about the young men in the hospital wards. "To these, what are your dramas and poems, even the oldest and the tearfulest?" he wrote in mid-March to a couple of his Manhattan friends. 
Not old Greek mighty ones, where man contends with fate, (and always yields)-not Virgil showing Dante on and on among the agonized $\&$ damned, approach what here I see and take a part in. For here I see, not at intervals, but quite always, how . . . our American man-how he holds himself cool and unquestioned master above all pains and bloody mutilations. It is immense, the best thing of all, nourishes me of all men. ${ }^{23}$

Democracy is thus a matter of inner strength rather than political philosophy. And yet a doubt persisted: was Whitman's society, despite its lip-service to democracy, really grounded in that kind of democratic character?

In the second passage Whitman takes on that question, challenging Democracy not with the physical and psychological horror of war but with a "terrible query." ${ }^{4}$ Given the fact that we see all around us "the shallowness and miserable selfishness <ism> of vast <these> crowds of men," Whitman asks rhetorically, how can we avoid the conclusion that "human rights" are only "humbug after all"? On his daily walks Whitman had observed that the nation's capital was full not just of wounded soldiers but of "all this huge mess," as he wrote a friend in early May, "of traitors, loafers, hospitals, axe-grinders, \& incompetencies \& officials that goes by the name of Washington." 25 How can courageous youth be asked to die "upon the cross" for this mass of men who have nothing but "souls of chalk"? Why should even one young man, let alone thousands, die for "these flippant people with hearts of rags"?

This is a tough question, one that Whitman does not resolve in this draft paragraph. But the move he makes toward a resolution is extremely interesting. He now tries out the idea that democracy is essentially a belief - not a solid institution whose walls we defend, but rather a dynamic, sometimes elusive faith that somehow makes stronger those who commit themselves to it. To men with "souls of chalk" such an idea is an illusive fantasy, mere humbug. But democracy is no empty dream to those who not only preach its ideals but give themselves fully to make those ideals real, men like those in the army hospitals whose courage and selflessness and patriotism moved Whitman to tears. The quest for democracy transforms such men into heroes with almost godlike stature.

This does not mean, of course, that they become invincible. On the contrary, these democratic heroes become Christ-like suffering servants whose sacrifice for others leads ultimately to death "upon the cross." Nor is there any assurance that their deaths will redeem their society. In fact Whitman leaves us with the potentially nihilistic irony that the democratic quest that transforms these boys into heroes, may, at least in this time and place, require their death: "gods it makes," he concludes, "though it crucifies them often." This has the ring of a profound aphorism with Nietzschean overtones, especially when read in the light of Lincoln's death two years later. But, for better or worse, Whitman took 
it no further here, perhaps because that quasi-theological water was too deep and dark for the kind of inspirational lecture he had in mind.

The third passage on "Democracy" is the longest, the most complex, and the most moving. Whitman opens it with a sketch, inviting us to picture in our minds a "<strong> Imperial Stern Democracy," something like a Wagnerian heroine roused to triumphant anger by "this hot rebellious rise we call the south." 27 Assuming the loud voice of this stern avenger, Whitman issues an ultimatum to the rebels, reinforced by a bloody curse: if you "dare to lift the knife against to plunge it at my breast, learn what it is to rouse the devil-on your head be the red blood, and on your children's heads." Such a furious tantrum was, of course, quite out of character for Whitman himself in the spring of 1863 . On the contrary, when others got angry about the political dimensions of the war, it was more typical of him, as he put it in a letter that July, to "remain silent, partly amused, partly scornful, or occasionally put a dry remark, which only adds fuel to the flame." 28

But perhaps this political detachment, so distinct from his angry sarcasm in the 1850s (see, for example, his jeremiad of 1856 , "The Eighteenth Presidency!"), was part of the psychological problem he was dealing with through his invention of, and vicarious participation in, a melodramatic tirade against the South. Perhaps he was seeing what would happen if his rhetoric succeeded in igniting a fiery blast of righteous anger. Would such anger transform him and his audience into heroic defenders of democracy, or pervert them into blood-thirsty avengers? Or was it possible that such wrath might somehow lead to an emotional purging, so that, as in a revivalist's sermon, the heat of righteous anger would melt the hardened heart?

The manuscript breaks off in mid-sentence at the bottom of page 155 , as if Whitman were lost in this imagined rage, as if he could not quite see where the angry curse, the hot temper, was leading him. But then an actual event in his life apparently became a threshold moment for him, opening up a perspective that allowed him, or forced him, to convert the trumped-up, hypothetical anger of "Imperial Stern Democracy" into a physical sensation of brotherly love welling up in the heart.

Standing on Pennsylvania Avenue one day in early May, Whitman watched as a hundred wretchedly dressed Confederate prisoners of war, probably swept up in an early skirmish of the battle for Chancellorsville, trudged by on their way to prison. ${ }^{29} \mathrm{He}$ was so close to them that their reality, their concrete immediacy, punctured the inflated hyperbole of his imagined rage. Or so it seemed when he returned to his daybook and wrote out a long confession, attaching it to the "curse" passage on the previous page with an emphatic "see over" and a couple of hand-drawn pointing fingers. 
We talk brave \& get excited $\&$ indignant over the "rebels," \& drink perdition to thembut I realized how all anger sinks into nothing, in sight of these young men \& standing close by them, $\&$ seeing them pass. ${ }^{30}$

The emotional deflation is sudden and complete: "All anger sinks into nothing," not because there has been no bloody offense, but because Whitman is close enough to see in their eyes that they are nevertheless "my brothers just about the same as the rest."

And then, he writes, he cried. Having broken through both his personal detachment and his melodramatic invention of rage, he suddenly felt welling up within him the fraternal love that is the emotional core of democracy.

I felt my heart full of compassion \& brotherhood \& the <irrepressible absurd> tears started in my eyes, - these too are my brothers-it was in the look of them \& in my heart-the common people these, American, silent proud young fellows[.] ${ }^{31}$

Not fantasized rebels now, these too are simply "the common people ... American," the source and true finale of democracy.

These ragged and dirty young prisoners of war are more than just fellow Americans, however, for like their counterparts in the Union hospitals, they are distinguished by having suffered. Again Whitman introduces a paradox rooted in Christianity, now not the figure of a crucified god but rather a revolutionary irony:

To haave [sic] suffered! what a title it gives!-all the honors, the President <at his levee $>$, the ribbon'd \& starr'd ambassadors . . . these must $\&$ shall yield place, curious as it seems, to prisoners underguard in war clothes, with wretched blankets, marched to prison, surrounded by armed guards. ${ }^{32}$

This is indeed a "curious" paradox, one that makes a profound political point: those who appear the least heroic, those who seem lost in suffering, may in fact be most worthy of honor, may be democratic heroes despite their overt status as prisoners of "Imperial Democracy," because through their suffering they have given proof of the inner strength on which democracy depends.

As with the crucified-god aphorism, Whitman soon gave up on this insight, leaving us with only another rough fragment. As far as I know he made no further use of these three passages on Democracy. Yet even in their unfinished state these rough drafts are worth close study, not as precursors or ephemeral dead-ends, but as small literary documents with their own value, much as spontaneous snapshots are often more evocative than studied portraits.

For one thing they raise interesting questions about the interplay of imagination and reality, about the intersection of Whitman's writerly 
work on paper and his personal experience in the world of war. Did Whitman really shed tears as those prisoners passed by? Or was the crying, like the cursing, a creative act of the imagination? We know that as he made his way through the hospital wards that spring Whitman had to consciously cultivate an aura of paternal calm, suppressing his own anguish in order to bring hope and confidence to the wounded and dying. "If you or Mat was here a couple of days," he wrote his mother in mid-April, "you would cry your eyes out. I find I have to restrain myself and keep my composure-I succeed pretty well." 33 Such restraint meant that his tears could be stored up as a kind of spiritual reservoir, the deep source of the music that flows through "A March in the Ranks HardPrest" or "Vigil Strange" or "When Lilacs Last in the Dooryard Bloom'd."

And yet that composure was not impregnable. I have a feeling that the "irrepressible absurd tears" Whitman recorded in the last Democracy passage were very real, the overwhelming experience of a man standing on the street, not a sublimation invented on paper. But I also suspect that the writing set up the crying, that the fantasized hot temper helped melt the heart. I can picture Whitman writing with inventive energy at his fifth-floor desk in the paymaster's office, conjuring up the melodramatic rant of "Imperial Stern Democracy" with his pencil, until, finding himself at a rhetorical dead end, he drifted down to Pennsylvania Avenue and suddenly found himself looking into the eyes of those rebel prisoners-“silent proud young fellows," his American brothers, the real image of democracy to which he was, at that moment, reconverted.

\section{Pacific Lutheran University}

\section{NOTES}

1 Clifton Joseph Furness, Walt Whitman's Workshop (Cambridge: Harvard University Press, 1928), 74-75. Hereafter cited as $W W W$.

2 Green leather diary, incipit title “a m Dr. L B Russell," pages 155-159, Harned Collection, Library of Congress (LC \#98). See microfilm reel 2, frames 82-85, sheets 1091-1093. Hereafter cited as "Daybook."

3 In a long endnote ( $W W W 226$, note 77 ), Furness printed some of the three pages he had skipped, claiming he had found this similar material in a later diary and speculating that it therefore fulfilled the "prophecy" of the supposedly earlier account! This gross error, so ingeniously rationalized, was no doubt a consequence of his haste and lack of organization in taking notes. As a graduate student looking for dissertation material, Furness spent a week at the Library of Congress in the spring of 1928, rushing through almost all of the recently opened Harned Collection. The notebook with his haphazard notes and transcripts is now in the Gay Wilson Allen Collection at Duke University. 
4 The unacknowledged three-page gap is between "years" (Daybook 155) and "these" (Daybook 158): "for . . twenty years, / these must . . y yield" ( $W W W 75$ ), which of course makes it impossible to find the antecedent of "these."

5 Charles I. Glicksberg, Walt Whitman and the Civil War (Philadelphia: University of Pennsylvania Press, 1933), 133-134. Hereafter cited as WWCW.

$6 W W W, 61-62$.

7 Notebooks and Unpublished Prose Manuscripts, ed. Edward F. Grier (New York: New York University Press, 1984), 2:533, 541-43. Hereafter cited as NUPM.

8 Daybook 142-44, 152-53, 155, in NUPM 2:541-542, 542, 543; but for Daybook 156-159 (continuing from 155), see NUPM 2:533. By running the first two passages together on the same page (NUPM 2:542), Grier left the impression they form a single (incoherent) draft, though in fact they are quite distinct in the daybook, being separated by seven blank pages.

9 Daybook 156-159, NUPM 2:533.

10 Daybook 155, NUPM 2:543.

11 NUPM 2:543, note 66: "Description of parade of prisoners transposed to chronological order above." Unfortunately note 66 is attached to a phantom page reference, a gross typesetting error that slipped by both editor and proofreader. In fact the notes for this passage (notes 66-70) are all misplaced or otherwise muddled. A corrected version would read "twenty years, ${ }^{67}$ my hand will have $[163,1095]^{\text {to }}[165$, $1096 \mathrm{R} ; 156-159 ;^{66} 160 ;^{6768} 161$ blank; $\left.162 ;^{6870} 163^{69}-164^{7069 a}\right]$." The superscript numbers are out of sequence because they keep their reference to Grier's notes-except for ${ }^{69 a}$, a new note that would read "transferred to p. 535."

12 Incipit title "Return My Book," Harned Collection, Library of Congress (L.C. \#94), NUPM 2:478-524, one of the lost notebooks recently found and made available on the LC website.

13 Whitman to Ralph Waldo Emerson, December 29, 1862, The Correspondence, ed. Edwin Haviland Miller (New York: New York University Press, 1961) 1:61, \#26. Hereafter cited as Corr.

14 Whitman to Nathaniel Bloom, September 5, 1863, Corr. 1:142, \#74.

15 See articles in the Brooklyn Daily Eagle for January 5 \& March 19, 1863; in The New York Times for February 26, August 16, \& October 4, 1863; and in the Brooklyn Daily Union for September 22, 1863.

16 Whitman to Martha Whitman, January 3, 1863, Corr. 1:63, \#27.

17 Whitman to Ralph Waldo Emerson, January 17, 1863, Corr. 1:69, \#32.

18 Whitman to Louisa Whitman, June 9, 1863, Corr. 1:109, \#53.

19 NUPM 2:541-542.

20 Grier capitalized “Civil War," but the letters look lower case to me. See LC \#98, Harned Collection, Library of Congress, reel 2, frame 82, sheet 1086 verso.

21 Whitman to Louisa Whitman, July 7, 1863, Corr. 1:114, \#56.

22 NUPM 2:542. I follow Grier's transcript, though I think I see: "if worse than these be <if any thing more monstrous, more unnatural be than these others $>$." Daybook, 144 (LC \#98, reel 2, frame 81, sheet 1087 verso). 
23 Whitman to Nathaniel Bloom and John F. S. [Fred] Gray, March 19, 1863, Corr. $1: 82$, \#40.

\section{NUPM 2:542.}

25 Whitman to Moses Lane, May 11, 1863, Corr. 1:99, \#47.

26 NUPM 2:542.

27 NUPM 2:543. Grier missed the clear capitalization of "Imperial."

28 Whitman to Louisa Whitman, July 15, 1863, Corr. 1:117, \#58.

29 Whitman drafted what seems to be a generalization of this same experience in the notebook stamped Christian Commission, with the incipit title "Walt Whitman Soldier's," Harned Collection, Library of Congress (L.C. \#99), NUPM 2:607: "the processions of rebel <secesh $>$ prisoners, all ragged \& dirty, a poor huge raff, yet through the dirt $\&$ rags the American face $\&$ form, strong $\&$ clean appears . . . no remarks from the crowd,-I have seen them often, yet never heard one sign of jeer or offensive exultation-." (Also in Glicksberg, $W W C W, 163$.) Though this notebook entry is undated, the next page is dated May 3,1863. On May 5 Whitman reported a similar experience (perhaps the same) in a letter to his mother, this time including reference to his tears: "Mother, while I have been writing this, a very large number of southern prisoners, I should think 1000 [?] at least, has past up Pennsylvania avenue, under a strong guard. I went out in the street, close to them, to look at them. Poor fellows, many of them mere lads - it brought the tears, they seemed our own flesh \& blood too, some wounded, all miserable in clothing, all in dirt \& tatters-many of them fine young men. Mother, I cannot tell you how I feel to see these prisoners marched" [holograph incomplete]. (Corr. 1:98, \#46.)

30 NUPM 2:533.

31 I correct Grier's transcript, which reads as follows: "the common people these Americans-silent proud young fellows" (NUPM 2:533). Glicksberg's version is accurate at this point (WWCW 134). See LC \#98, reel 2, frame 84, sheet 1092.

32 Where Grier transcribed "man [?] clothes" (NUPM 2:533), both Furness (WWW 226, note 77) and Glicksberg (WWCW 134) saw "war clothes." Whitman's script is unclear, but the Furness and Glicksberg reading makes more sense.

33 Whitman to Louisa Whitman, April 15, 1863, Corr. 1:90, \#42. 